\title{
The central European floods of August 2002: \\ Part 2 - Synoptic causes and considerations with respect to climatic change
}

\author{
Uwe Ulbrich, Tim Brücher, Andreas H. Fink, Gregor C. Leckebusch, \\ Andreas Krüger and Joaquim G. Pinto \\ Institute for Geophysics and Meteorology, University of Cologne, Germany
}

In the first part of this paper (Ulbrich et al. 2003), we gave a description of the August 2002 rainfall events and the resultant floods, in particular of the flood wave of the River Elbe. The extreme precipitation sums observed in the first half of the month were primarily associated with two rainfall episodes. The first episode occurred on 6/7 August 2002. The main rainfall area was situated over Lower Austria, the south-western part of the Czech Republic and south-eastern Germany. A severe flash flood was produced in the Lower Austrian Waldviertel ('forest quarter'). The second episode on 11-13 August 2002 most severely affected the Erz Mountains and western parts of the Czech Republic. During this second episode $312 \mathrm{~mm}$ of rain was recorded between 0600 GMT on 12 August and 0600 GMT on 13 August at the Zinnwald weather station in the Erz Mountains, which is a new 24-hour record for Germany. The flash floods resulting from this rainfall episode and the subsequent Elbe flood produced the most expensive weatherrelated catastrophe in Europe in recent decades.

In this part of the paper we discuss the meteorological conditions and physical mechanisms leading to the two main events. Similarities to the conditions that led to the recent summer floods of the River Oder in 1997 and the River Vistula in 2001 will be shown. This will lead us to a consideration of trends in extreme rainfall over Europe which are found in numerical simulations of anthropogenic climate change.

\section{Synoptic situation during 1-15 August 2002}

At the end of July 2002 an upper-tropospheric trough developed west of Ireland. It formed a cut-off low centred over north-western France and Belgium from 1 August. A surface low, which developed below the upper-tropospheric depression, led to an incursion of cool air from the Atlantic into western Europe, replacing the warm and humid airmasses previously resident over the Continent. Widespread thunderstorm activity and local rainfall extremes in northern Germany were associated with a cold front and a secondary low which moved over Germany towards the Baltic Sea at the beginning of the month. During the following days, the region north of the Alps remained under the influence 


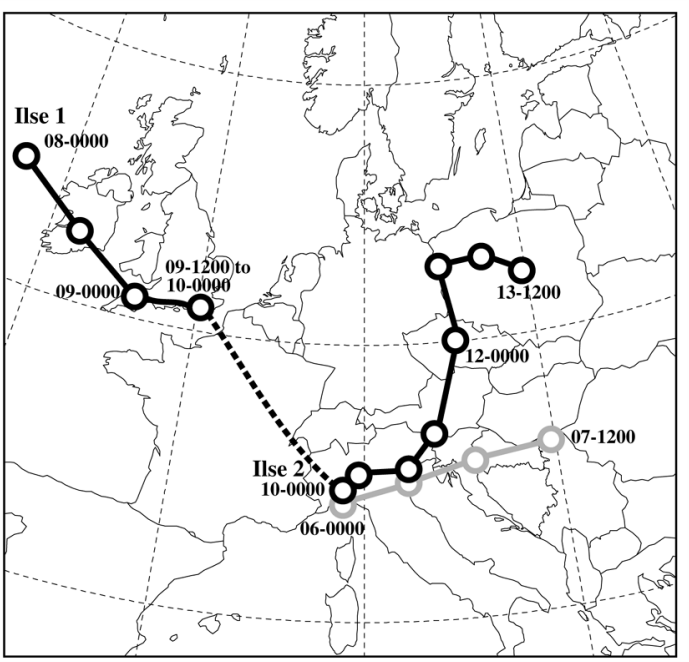

Fig. 1 Tracks of the surface lows relevant to the extreme rainfall events. Positions are given at 12-hourly intervals, partly giving reference to both day (of August 2002) and time (GMT). Grey: unnamed low moving eastwards from 0000 GMT on 6 August to 1200 GMT on 7 August. Black: low named Ilse, with an initial position west of Ireland at 0000 GMT on 8 August. The apparent movement from a position over southern England, at 1200 GMT on 9 August, to the Alps (dashed line) is connected to the formation of a secondary low (named Ilse 2) at $0000 \mathrm{GMT}$ on 10 August. The former core (renamed Ilse 1) was still identified over south-east England at the same time. The last position shown for Ilse 2 is at 1200 GMTon 13 August.

of the cool air, and a temperature contrast between the areas north and south of this mountain range was established $\left(16^{\circ} \mathrm{C}\right.$ in Konstanz, Germany, and $25^{\circ} \mathrm{C}$ in Milan, Italy, at 1200 GMT on 6 August).

On 6 August, a weak low formed in the Gulf of Genoa in connection with the frontal system of the surface low, now over The Netherlands. This new system moved across northern Italy and the Adriatic Sea towards southern Hungary (Fig. 1), but it remained very shallow. When rainfall maxima were observed in Lower Austria before midnight on 6 August and during the afternoon of 7 August, the system's core was located at some distance from the rainfall area south-east of Austria (Fig. 1). On 7 August surface charts show a convergence line over central Europe at both 1200GMT (Fig. 2(a)) and 1800 GMT (not shown). At the same time, the quasi-stationary depression at upper levels split into two parts located north and south-east of the Alps (Fig. 2(b)).
Evidence will be given later that this was important in the development of the first intense rainfall event.

On 8 August, only weak and very smallscale remnants of the upper-tropospheric depression over central Europe could be identified. A new cold air outbreak directed towards western Europe commenced on the same day, leading to a new large upper-tropospheric depression with a core over northern France on 10 August. At the surface, this depression was associated with a low named Ilse by Deutscher Wetterdienst (the German Weather Service). This cyclone appeared west of Ireland at 0000 GMT on 8 August (Fig. 1), and moved to southern England by 1200 GMT on 9 August. This surface low remained over southern England until 0000 GMT on 10 August, and subsequently filled (not shown). At upper levels, however, the cut-off low continued to move southwards to reach central Italy by 1200 GMT on 11 August. This upper-tropospheric development supported the formation of a secondary low (Ilse 2, Fig. 1) over the Gulf of Genoa on 10 August, while the old core (now renamed Ilse 1) was still present over southern England. Ilse 2 slowly moved eastwards until $0000 \mathrm{GMT}$ on 11 August, subsequently turning northwards (Fig. 1). At this time, the first intense rainfalls of this period were observed east of Lake Constance (Bavarian Water Board 2002), and later, on 12 August, in the Salzburg area, the western Czech Republic and the Erz Mountains. At 1200 GMT on 12 August, the surface analysis produced by the Deutscher Wetterdienst shows a partly occluded frontal system stretching northwards from the centre of the low along the German-Polish border (Fig. 3(a)). Northerly surface winds of $15-25 \mathrm{kn}$ between eastern Germany and the Austrian Alps were induced by the strong pressure gradient on the low's western flank. The northward movement of the surface low was associated with the northeastward displacement of the upper-tropospheric depression mentioned earlier, which had a position south-east of Germany and the Czech Republic on 12 August (Fig. 3(b)). Both the surface low (Fig. 1) and the upper-air depression advanced eastwards on the following day. 
(a)

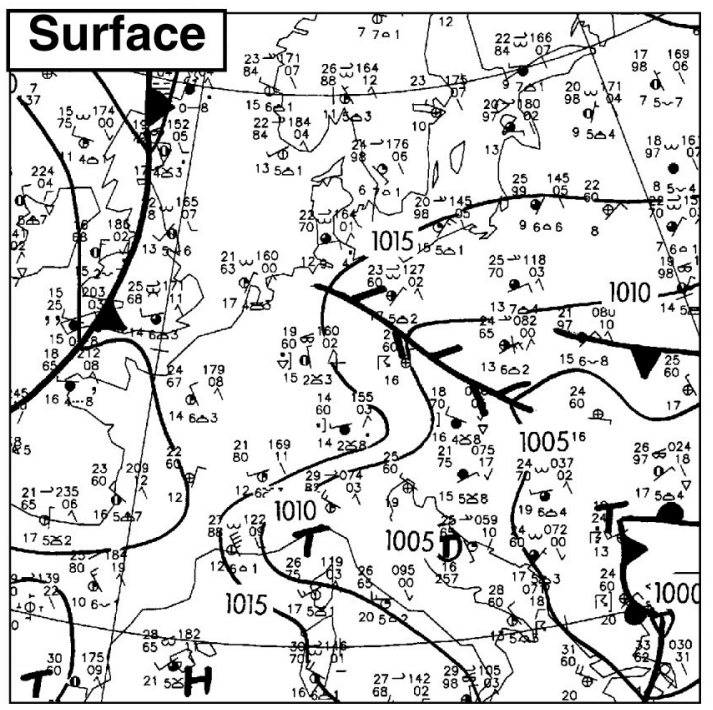

(c)

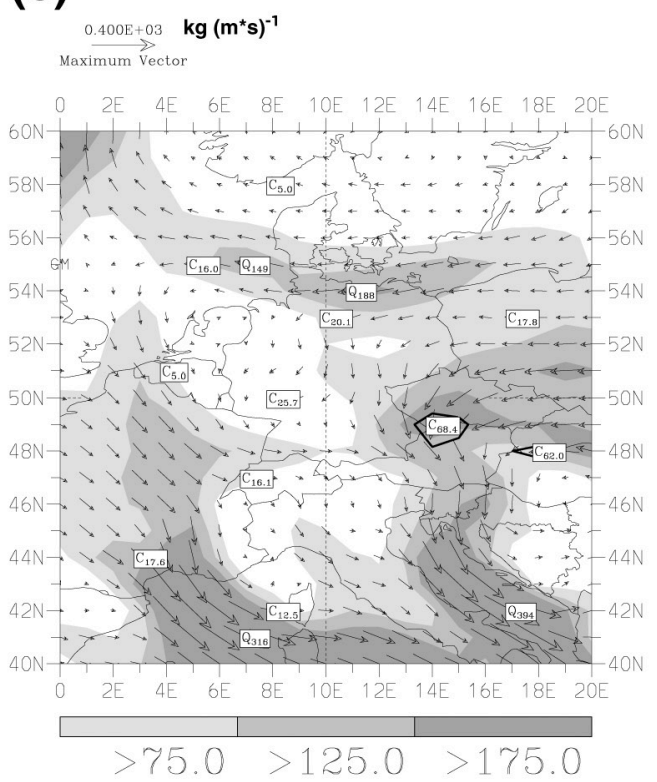

(b)

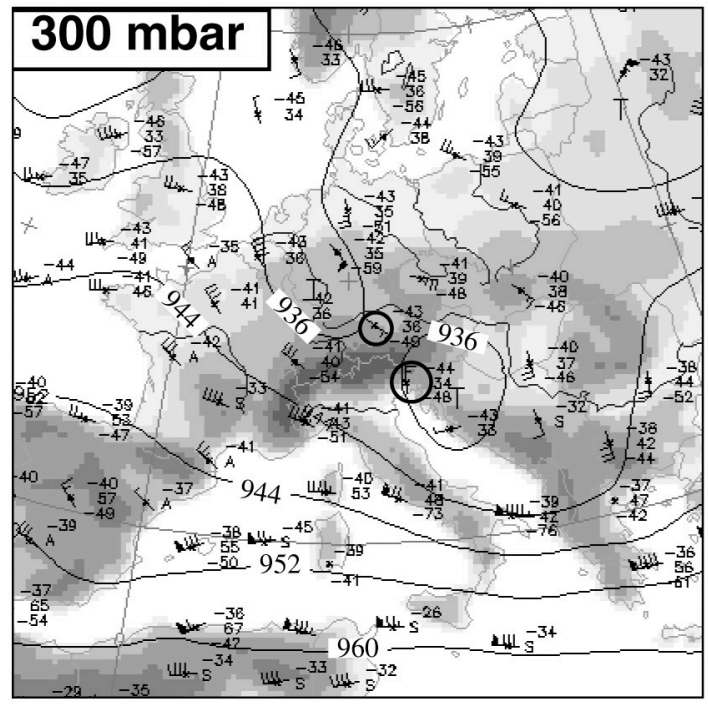

(d)

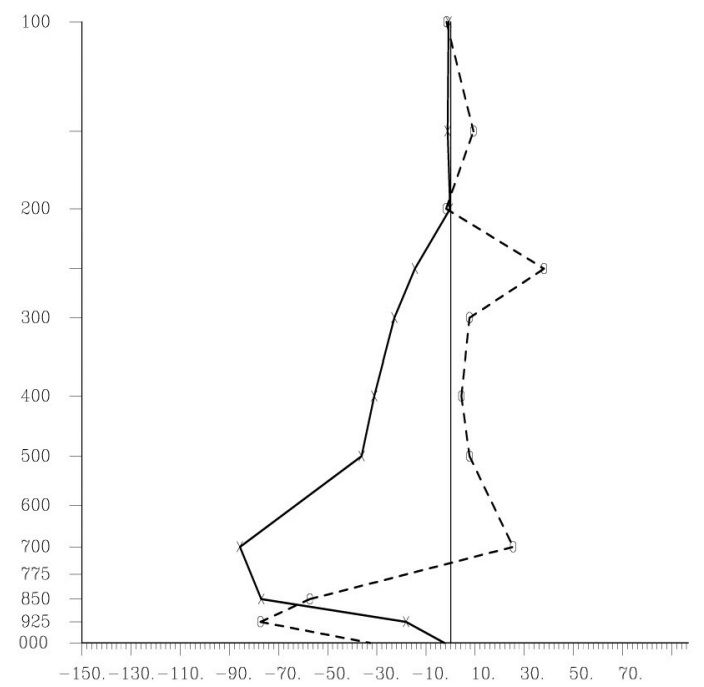

Fig. 21200 GMT on 7 August 2002: (a) Surface analysis (source: European Meteorological Bulletin). (b) 300 mbar analysis (units dam). (c) Lower-tropospheric moisture flux (intensity indicated by shading, units $\mathrm{kg} \mathrm{m}^{-1} \mathrm{~s}^{-1}$, direction given by arrows) computed from the operational ECMWF analysis. Isolines indicate areas of more than $50 \mathrm{~mm}^{-1 a y^{-1}}$ total tropospheric moisture flux convergence (approximately equivalent to rainfall intensity). Maxima of moisture fluxes and flux convergence are labelled $Q_{x}$ and $C_{x}$, respectively. (d) Vertical profile of vertical velocity (solid line, units $10^{-4}$ mbars $^{-1}$, upward directed winds have negative values) and horizontal wind divergence (dashed line, units $10^{-6} \mathrm{~s}^{-1}$ ) for the area $48-49^{\circ} \mathrm{N}, 14-15^{\circ} \mathrm{E}$.

\section{Physical mechanisms associated with the two main rainfall events}

Our first focus is the second, more intense rainfall event of 12 August. The record-breaking rainfalls were associated with a broad tongue of extremely warm and humid lower-tropospheric air extending from Greece to Denmark. The temperature and moisture content of the lower-tropospheric air involved in the event 
(a)

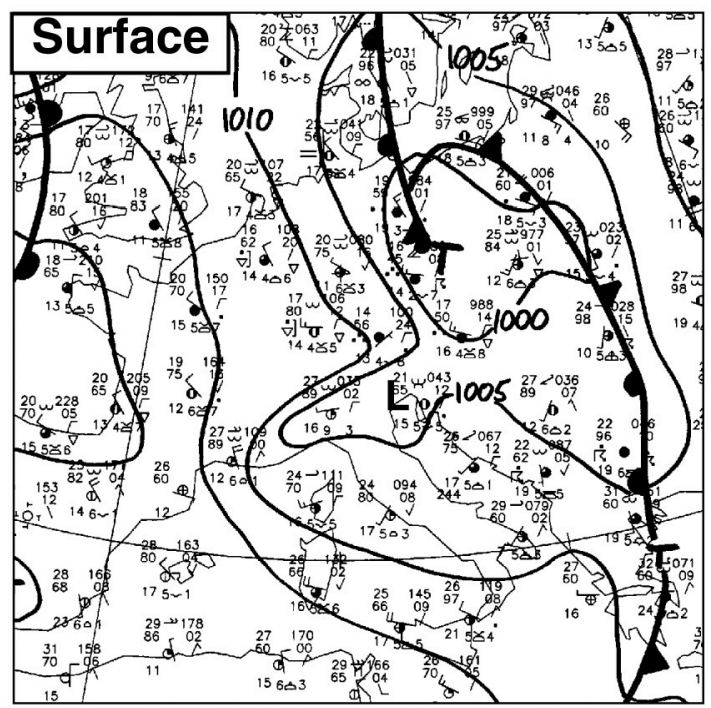

(c) (b)

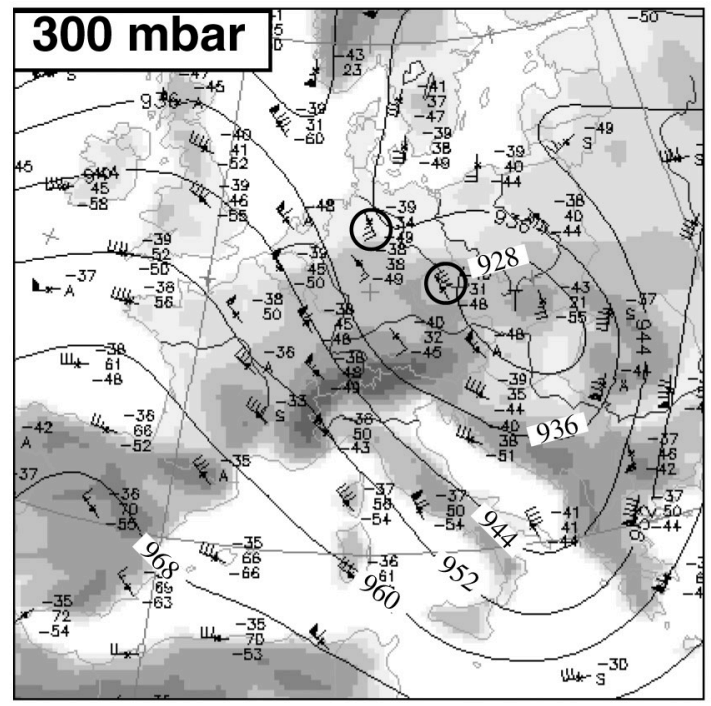

(d)

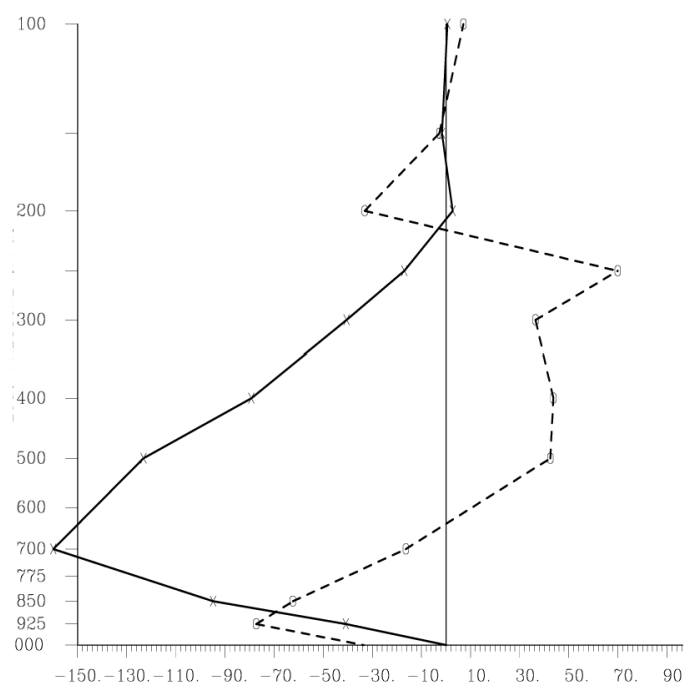

Fig. 3 As Fig. 2, but for 1200 GMTon 12 August 2002. Isolines plotted in (c) are 50, 70 and $90 \mathrm{~mm}$ day ${ }^{-1}$. The area used in (d) is $51-52^{\circ} \mathrm{N}, 13-14^{\circ} \mathrm{E}$.

were very high. The importance of advection from the western Mediterranean Sea in the formation of this tongue is confirmed by an analysis of back trajectories (Fig. 4, inside front cover). Note that the back trajectories indicate eastward advection over the Mediterranean Sea prior to the formation of Ilse 2. It is obvious that the cyclone's movement from the Gulf of
Genoa towards eastern central Europe played a significant role in the course of the moist air around the Alps. At 1200 GMT on 12 August 2002, the low's frontal system (with westward advection of warm and humid air) and the northerly flow west of the cyclone core were two essential factors leading to the extreme rainfall event in the Erz Mountains area. 
Weather radar echoes (not shown) suggest a predominance of easterly flow and thus of frontal lifting during the early morning of 12 August, while later the strong southward advection (and thus orographic lifting towards the Erz Mountains) became important. Both major flow directions are reflected in the integrated low-level moisture fluxes between the surface and 700 mbar (shown in Fig. 3(c)).

Observed rain rates and analysed moisture convergence in the troposphere (indicated by the isolines in Fig. 3(c)) appear to be consistent. Maximum convergence rates in the analysis for $1200 \mathrm{GMT}$ are equivalent to a rain intensity of up to $97 \mathrm{mmday}^{-1}$, i.e. about $0.7 \mathrm{~mm}$ in 10 minutes. Observed rainfall intensities for this time period (Fig. 4 in Ulbrich et al. 2003) are in a range between $3 \mathrm{~mm}$ (Zinnwald) and about $0.3 \mathrm{~mm}$ (Fichtelberg) in 10 minutes.

The European Centre for Medium-Range Weather Forecasts (ECMWF) analysis for the same time shows upward vertical winds throughout the troposphere, with a maximum of $0.015 \mathrm{mbars}^{-1}$ at $700 \mathrm{mbar}$ (Fig. 3(d)). They are associated with low-level convergence, and divergence maxima between 500 and 250 mbar. The large divergence near the tropopause is a peculiarity of the profile. This outflow could be produced by latent heat release below, but this would be more typical of tropical convection than a midlatitude depression. We thus prefer the view that horizontal divergence was enhanced by directional divergence of the upper-air flow north-west of the cut-off low, which is also evident from the 300 mbar radiosonde winds encircled in Fig. 3(b). Also, both local human observations and maps of sferics` (e.g. Deutscher Wetterdienst 2002) suggest that there was hardly any thunderstorm activity in the main rainfall regions, with a few exceptions (e.g. Prague, 1200 GMT on 12 August, Fig. 3(a)).

With respect to the first rainfall event on 7 August 2002, there was also a mid-tropospheric inflow of warm air from the Mediterranean Sea but, as revealed by the back trajectories in Fig. 5 (inside front cover), the humid air at lower levels approached central

^ Locations of lightning flashes.
Europe from eastern to northern origins. Lower-tropospheric water-vapour flow into the main rainfall area was similar to the situation of 12 August, with a prevailing north to northeasterly flux (Fig. 2(c)). Thus, orographic lifting associated with the upward slope of the Waldviertel certainly contributed to the extreme rainfall amounts. Moisture flux convergence in the troposphere (Fig. 2(c)) was somewhat less than on 12 August (Fig. 3(c)). It was associated with a line of convergence (Fig. 2(b)) in this area. Uplift above the 500 mbar level was less intense on 7 August (Fig. 2(d)) than on 12 August (Fig. 3(d)). This can be understood from upper-tropospheric divergence which was weaker than during the second event, even though wind arrows in Fig. 2(a) also reveal diffluent upper-air flow.

In summary, we suggest four main synoptic causes for the extreme summer rainfalls of August 2002:

(i) Very humid air, advected at low- to midtropospheric levels from the western Mediterranean basin around the Alps.

(ii) Frontal uplift or a convergence line, stalling over the affected areas for a significant length of time (about 24 hours).

(iii) Orographic lifting associated with airflow up the northern slopes of the central European mountain ranges, to the north-west or west of the low's core.

(iv) The occurrence of these conditions is connected with an upper-level trough or depression over central Europe which contributed to the dynamically induced upper-level divergence and which also provided the large-scale steering flow for the surface low. Both the upper-level trough and the surface low moved only slowly or remained quasi-stationary so that the area remained under atmospheric conditions conducive to extreme rainfall for some time.

\section{Comparison with recent floods in the same area}

Severe summer floods have affected the Rivers Oder and Vistula in recent years. In 1997 both the Oder and the Vistula swelled to levels that 
had return periods of the order of 1000 years at some gauging stations (Kundzewicz et al. 1999). The floods were produced by a sequence of two intense rainfall periods (4-9 and 17-22 July 1997) affecting southern Poland, Austria and eastern parts of the Czech Republic (Fuchs and Rapp 1998, Figs. 2 and 3). Cumulative rainfall amounts for July 1997 were of the order of 300 to $500 \%$ of the average July precipitation. At the mountain station of Lysa Hora (located at $49^{\circ} 33^{\prime} \mathrm{N}, 18^{\circ} 27^{\prime} \mathrm{E}$, Beskides Mountains, Czech Republic) $585 \mathrm{~mm}$ of rain was reported between 4 and 9 July. The monthly sum of $811 \mathrm{~mm}$ at this station is more typical of monsoon rainfall. The first of the rainfall periods can be assigned to the low named Xolska by the Deutscher Wetterdienst, which moved from Italy into central Europe (Fig. 6). The second rainfall event was associated with the low named Zoe which took a somewhat more westerly path from the Balearic Islands towards the Alps, forming a

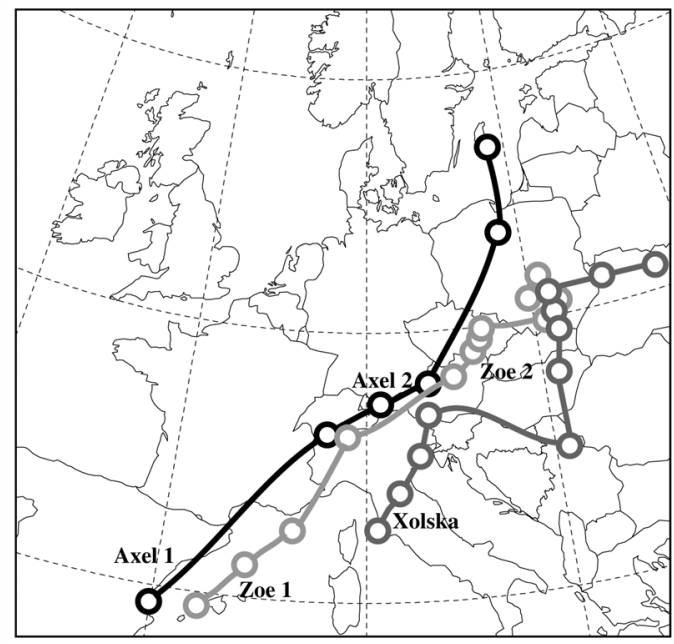

Fig. 6 Tracks of the surface lows relevant to the floods of 1997 and 2001. Positions are given in 12-hourly intervals. Dark grey: Low Xolska, moving north-eastwards from OOOO GMT on 4 fuly 1997 (Italy) to OOOO GMT on 9 fuly 1997 (Ukraine). Light grey: Low Zoe, moving north-eastwards from the Balearic Islands (OOOO GMT on 16 fuly 1997). A secondary low (Zoe 2) forms over the southern Czech Republic at OOOO GMT on 18 fuly 1997. Black: Low Axel, moving from the Iberian peninsula (OOOO GMT on 15 fuly 2001) to a position south of the Alps within 12 hours. A secondary core (Axel 2) is generated further north-east at 1200 GMT on 15 fuly 2001, and reaches Gotland at 0000 GMT on 17 fuly 2001. The low of the second rainfall event associated with the Vistula flood of 2001 is not included in the figure. secondary low on 18 July 1997 (Zoe 2) which slowly progressed into southern Poland (Fig. 6). Both surface lows were associated with upper-tropospheric cut-off lows over south-eastern Europe.

The flooding of the Vistula in summer 2001 also originated from two extreme rainfall periods (16/17 and 21-27 July 2001). Again, large areas in southern Poland and neighbouring countries were affected by torrential rains. Observed rainfall amounts and spatial extension of the rainfall area in 2001 were not as large as for the 1997 flood, but monthly rainfall sums at several stations in southern Poland amounted to about three times as much as the climatological mean. For example, $290 \mathrm{~mm}$ (337\% of average July precipitation) was reported at Kielce $\left(50^{\circ} 49^{\prime} \mathrm{N}, 20^{\circ} 42^{\prime} \mathrm{E}\right)$ for July 2001, and $610 \mathrm{~mm}(292 \%)$ was reported at Kasprowy-Wierch $\left(49^{\circ} 14^{\prime} \mathrm{N}, 19^{\circ} 59^{\prime} \mathrm{E}\right)$ (Fuchs and Rudolf 2002). The cyclone track associated with the first rainfall episode (Axel 1, Fig. 6) came from the western Mediterranean, forming a secondary low on 16 July 2001 (Axel 2, Fig. 6). The development at the surface took place at the eastern flank of a large-scale upper-tropospheric trough over western Europe. The second rainfall period of the 2001 flood was associated with a low that moved into south-eastern Europe from the Black Sea, thus differing from the others. It was, however, also connected with a cut-off upper low over south-eastern Europe.

The synoptic situations of the August 2002 floods and those of the two other recent floods described above are rather similar. They were generally associated with surface lows which moved from the Mediterranean Sea to central Europe on a path over (or near) the eastern Alps. The importance of this specific class of tracks for the generation of summer floods in central Europe has long been recognised (Van Bebber 1891). In his classification of typical cyclone paths over Europe, Van Bebber called them 'Vb-tracks', a notation still used among German meteorologists. The Vb-tracks have a rather high potential for leading to extreme rainfall by contributing to the main synoptic causes identified for the rainfall events of 2002: advection of humid air, frontal uplift, and airflow up the northern slopes of the mountains. 


\section{Climatic change simulations}

The recent summer floods in central Europe led to a public discussion of whether these events were indicative of ongoing anthropogenic climate change. Numerical simulations performed using global circulation models (GCMs) provide a basis for estimating climate change due to increasing greenhouse-gas concentrations. These models generally produce a decrease of summer rainfall in the Mediterranean region, and Parry (2000, Fig. B8) suggests that in most models the region with decreasing summer precipitation reaches northwards into central Europe, with a reduction of $7-8 \%$ in the 2050 s and $11-12 \%$ in the 2080 s at the respective grid points. At first glance, these results seem to suggest a decreasing risk of summer floods in a changing climate. Changes in seasonal mean precipitation may, however, be inappropriate for estimating a changing risk of extreme rainfall. Therefore, we explored the probable change of daily rainfall in central Europe using two GCMs: ECHAM4/OPYC3 (Bacher et al. 1998) and HadCM3 (Carson 1999; Hulme et al. 1999). The models were programmed to assume economic development without major emission reductions ('business as usual').

A comparison of present-day climate with climate towards the end of the present century (two 30-year periods considered) suggests a shift towards heavy precipitation events in both models (Fig. 7), while total summer rainfall decreases. This result is consistent with other recent publications (Booij 2002; Christensen and Christensen 2003). The simulated increase of days with intense summer rainfall is associated with an increasing number of meridional weather situations, comprising a trough over western or central Europe. This is the weather situation also observed during the recent floods.

\section{Concluding remarks}

The Elbe flood of August 2002 was caused by extreme rainfall in a large area. The associated circulation pattern was rather typical of previous flood events both in recent years and in the more distant past (see Van Bebber 1891).
This situation is characterised by a surface low moving on a so-called Vb-track from the Mediterranean basin into central Europe. With respect to the summer 2002 events, a positive interference of several factors is suggested, including advection of humidity from the Mediterranean basin, a quasi-stationary position of the tropospheric trough which induces upper-level divergence, and orographic lifting due to northerly flow west of the surface low.

Extreme summer rainfall and resulting floods have always occurred in this region (Van Bebber 1891). The model simulations considered suggest that their frequency might increase in the future. According to Fricke and Kaminski (2001) an increase of days with extreme precipitation can already be observed in the long station time-series of the Hohenpeissenberg Observatory in southern Germany (1881-2001). For summer this increase is associated with an increasing frequency of weather types which are in turn associated with Vb-tracks (Fricke and Kaminski 2002). This seems to agree with the trends produced in simulations of anthropogenic climate change. It must, however, be stressed that it is difficult to determine trends of very rare events (Frei and Schär 2001), and we suggest that more detailed studies are performed on both the simulated and the observed synoptic development leading to extreme summer precipitation events in central Europe.

\section{Acknowledgements}

We wish to thank Deutscher Wetterdienst for permission to use ECMWF analysis data and the ECMWF trajectory package. The work was supported by the EU project MICE (Modelling the Impacts of Climate Extremes) under grant EVK2-CT-2001-00118.

\section{References}

Bacher, A., Oberhuber, J. M. and Roeckner, E. (1998) ENSO dynamics and seasonal cycle in the tropical Pacific as simulated by the ECHAM4/ OPYC3 coupled General Circulation Model. Clim. Dyn., 14, pp. 431-450

Bavarian Water Board (Bayerisches Landesamt für Wasserwirtschaft, Hochwassernachrichtendienst) (2002) Hochwasser im August 2002, mit 
(a)

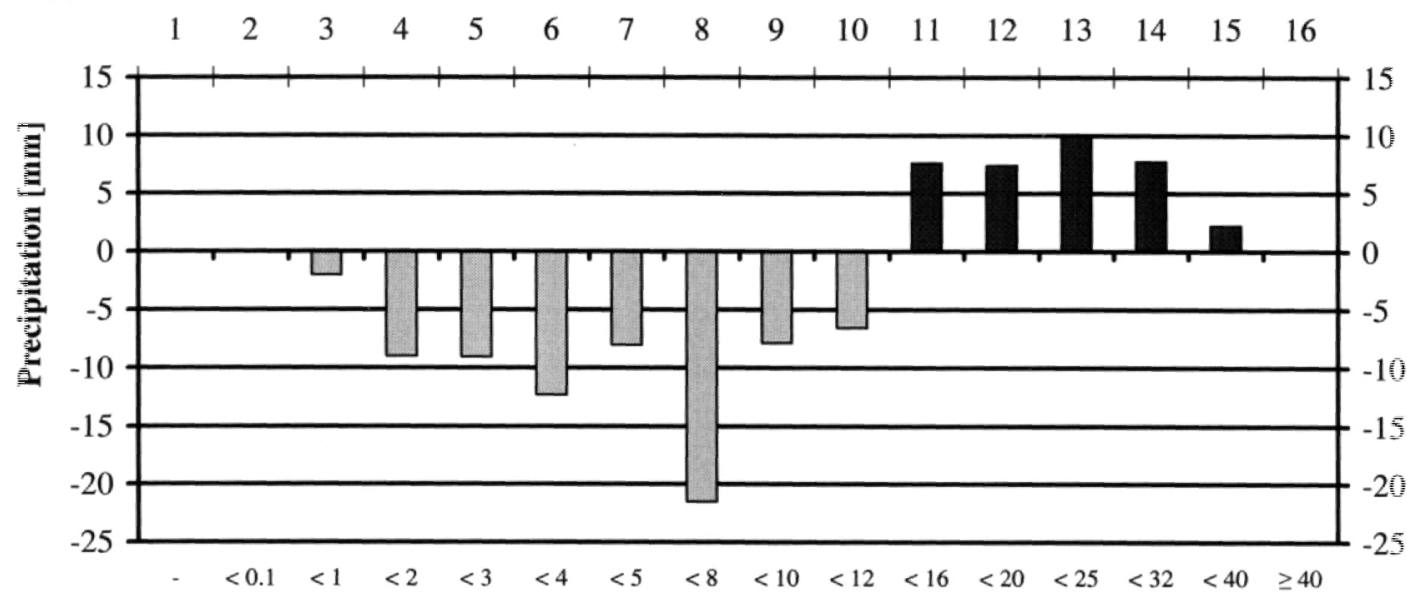

max. precipitation $[\mathrm{mm}]$

(b)

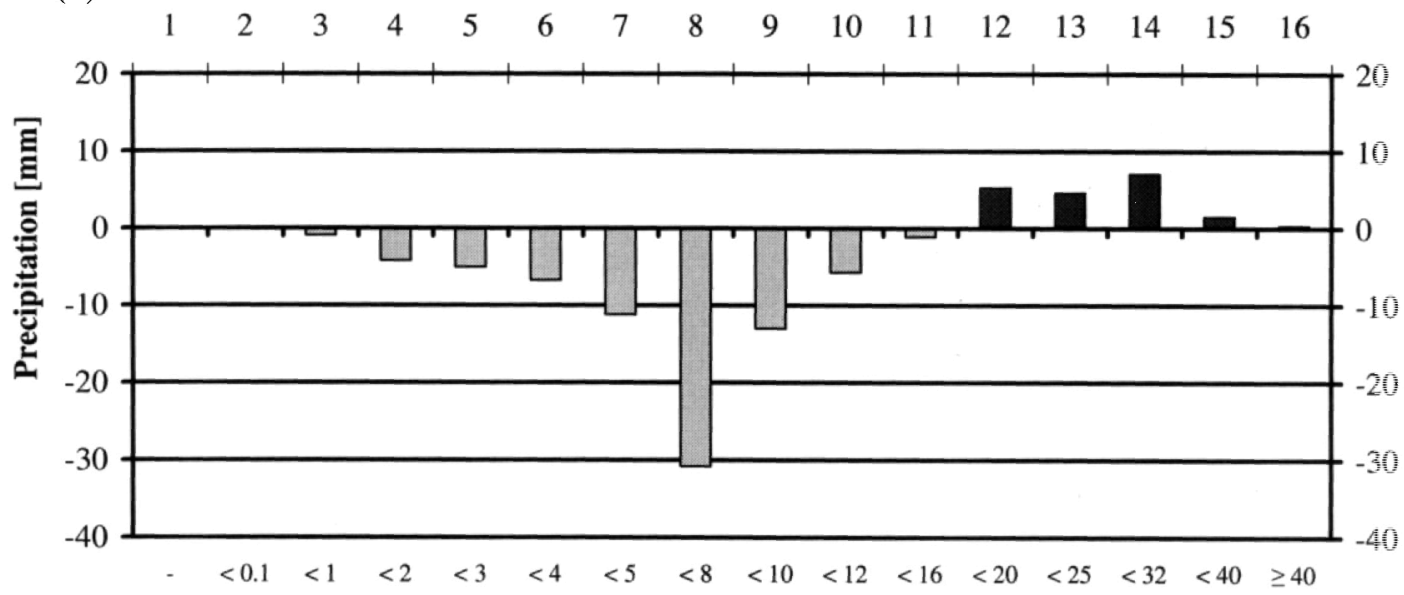

max. precipitation [mm]

Fig. 7 Climate change signal for the rainfall intensity distribution during summer (Fune, fuly, August). Precipitation sums for different intensity categories are accumulated, and the difference between two 30-year periods (representing a greenhouse-gas forcing of the periods assigned to the years 2060-89 and 1930-59 according to the respective scenarios) is given: (a) at a central European grid point of the low-resolution coupled model ECHAM4/OPYC3 and (b) as (a) but for HadCM3, averaged for the four grid points surrounding Dresden, Germany.

Berichtigungen vom 28.10.2002. Available online from http: // www.bayern.de / lfw /hnd/hw1 10802/ titelseite.htm

Booij, M. J. (2002) Extreme daily precipitation in western Europe with climate change at appropriate spatial scales. Int. f. Climatol., 22, pp. 69-85

Carson, D. J. (1999) Climate modelling: Achievements and prospects. Q. F. R. Meteorol. Soc., 125, pp. $1-27$

Christensen, J. H. and Christensen, O. B. (2003) Severe summer flooding in Europe. Nature, 421, pp. $805-806$
Deutscher Wetterdienst (German Weather Service) (2002) Extreme precipitation amounts in central Europe from 1-13 August 2002. Available online from http://www.dwd.de/en/FundE/Klima/KLIS/ $\mathrm{prod} / \mathrm{spezial} / \mathrm{regen} / \mathrm{rr}$ _extreme_200208_germany. pdf

Frei, C. and Schär, C. (2001) Detection probability of trends in rare events, theory and application to heavy precipitation in the Alpine region. f. Clim. 14, pp. 1568-1584

Fricke, W. and Kaminski, U. (2001) GAW Brief des Deutschen Wetterdienstes, No. 5. Available online 
from http://www.dwd.de/de/FundE/Observator/ MOHP/hp2/gaw/gaw_briefe/gaw_briefe.htm (2002) GAW Briē des Deutschen Wetterdienstes, No. 12. Available online from http://www.dwd. $\mathrm{de} / \mathrm{de} / \mathrm{FundE} /$ Observator/MOHP/hp2/gaw/gaw briefe/gaw_briefe.htm

Fuchs, T. and Rapp, J. (1998) Zwei außergewöhnlich starke Regenepisoden als Ursache des Oderhochwasers im Juli 1997. Klimastatusbericht 1997, pp. 27-30, available online from German Weather Service http://www.dwd.de/research/klis/ ksb/ksb97/ksb0997.pdf

Fuchs, T. and Rudolf, B. (2002) Niederschlagsanalyse zum Weichselhochwasser im Juli $2001 \mathrm{mit}$ Vergleich zum Oderhochwasser 1997. Klimastatusbericht 2001, pp. 268-272, available online from: German Weather Service http://www.dwd.de/de/ FundE/Klima/KLIS/prod/KSB/ksb01/index.htm Hulme, M., Mitchell, J., Ingram, W., Lowe, J., Johns, T., New, M. and Viner, D. (1999) Climate change scenarios for global impacts studies. Global Environ. Change, 9, pp. S3-S19

Kundzewicz, Z. W., Szamalek, K. and Kowalczak, P. (1999) The great flood of 1997 in Poland. Hydrol. Sci. F., 44, pp. 855-870
Parry, M. L. (Ed.) (2000) Assessment of potential effects and adaptations for climate change in Europe: The Europe ACACIA project. Fackson Environment Institute. University of East Anglia, Norwich

Ulbrich, U., Brücher, T., Fink, A. H., Leckebusch, G. C., Krüger, A. and Pinto, J. G. (2003) The central European floods of August 2002: Part 1 Rainfall periods and flood development. Weather, 58, pp. 371-377

Van Bebber, W. J. (1891) Die Zugstraßen der barometrischen Minima nach den Bahnenkarten Deutschen Seewarte für den Zeitraum von 18751890. Meteorol. Z., 8, pp. 361-366

The online documents referenced above are mirrored under http://www.meteo.uni-koeln.de/ content/forschung/klimadiagnose/floods.html

Correspondence to: Dr U. Ulbrich, Institute for Geophysics and Meteorology, University of Cologne, 50923 Köln, Germany. e-mail: ulbrich@ meteo.uni-koeln.de

(C) Royal Meteorological Society, 2003.

doi: 10.1256/wea.61.03B 